\title{
INTERACTIONS BETWEEN COPPER AND CADMIUM MODIFY METAL ORGAN DISTRIBUTION IN MATURE TILAPIA, Oreochromis mossambicus
}

\author{
S. M. G. J. Pelgrom, L. P. M. Lamers, R. A. C. Lock, P. H. M. Balm \\ \& S. E. Wendelaar Bonga
}

Department of Animal Physiology, Faculty of Science, University of Nijmegen, Toernooiveld 1, 6525 ED Nijmegen, The Netherlands

(Received 27 July 1994; accepted 17 March 1995)

\begin{abstract}
Sexually mature female tilapia were exposed to sublethal concentrations of waterborne $\mathrm{Cu}$ and/or $\mathrm{Cd}$ over 6 days, and subsequent body concentrations of these metals were determined in several organs. The results show that the distribution of $\mathrm{Cu}$ and $\mathrm{Cd}$ was metal and organ specific. This is demonstrated, for example, by the observation that in tilapia, $\mathrm{Cu}$ exposure did not result in $\mathrm{Cu}$ accumulation in the liver, whereas in the intestinal wall, notably high concentrations of $\mathrm{Cu}$ and $\mathrm{Cd}$ were measured in metal exposed fish.

In addition to single metal exposed fish, we also determined $\mathrm{Cu}$ and $\mathrm{Cd}$ body distribution in $\mathrm{Cu}-\mathrm{Cd}$ co-exposed fish. The observed interactions in metal accumulation were most pronounced in the organs of fish exposed to low, environmentally realistic, metal concentrations.
\end{abstract}

Keywords: Copper, cadmium, metal accumulation, $\mathrm{Cu}-\mathrm{Cd}$ interaction, organ distribution.

\section{INTRODUCTION}

Heavy metals such as copper $(\mathrm{Cu})$ and cadmium $(\mathrm{Cd})$ are frequently present at elevated concentrations in freshwaters, generally as a result of industrial pollution. As a consequence, aquatic organisms, including fish, are exposed to elevated levels of these metals. $\mathrm{Cu}$, as an essential metal, plays an important role in cellular metabolism (Cousins, 1985) and its concentration is well regulated. However, exposure of fish to increased $\mathrm{Cu}$ concentrations results in $\mathrm{Cu}$ accumulation (Brungs et al., 1973; Buckley et al., 1982). As a result, various blood parameters (McKim et al., 1970; Christensen et al., 1972), enzyme activities in blood (Christensen and Tucker, 1976) and reproduction (Horning and Nieheisel, 1979) are affected. In contrast to $\mathrm{Cu}$, a biological function for $\mathrm{Cd}$ is unknown, and the metal is toxic to organisms at very low concentrations (Chmielnicka and Cherian, 1986). For example, exposure to $\mathrm{Cd}$ resulted in reduced growth, reproduction and survival in flagfish Jordanella floridae (Spehar, 1976). Also, Cd produces a variety of pathological effects in various organs in fish after acute exposure (Hawkins et al., 1980; KarlssonNorrgren et al., 1985).

No clear picture exists concerning the accumulation of $\mathrm{Cu}$ and $\mathrm{Cd}$ in fish tissues, partly because of differences in species, analytical techniques and experimental designs of the published studies (McCracken, 1987; Douben, 1989). More importantly however, each of the metals, $\mathrm{Cu}$ and $\mathrm{Cd}$, has been studied separately, not taking into account a possible concomitant influence of other metals. Few investigations have been made concerning the effect of one heavy metal on the accumulation of another metal in fish (Gill et al., 1992; Pelgrom et $a l ., 1994 a, b)$. Nevertheless, many of the toxic effects of $\mathrm{Cd}$ have been suggested to be the result of induced secondary deficiencies of essential trace elements, such as $\mathrm{Zn}$ and $\mathrm{Cu}$, since the uptake of $\mathrm{Cd}$ both modulates, and is modulated by, the uptake of these metals (Bremner, 1974). Since heavy metals often occur together in polluted areas, it is of importance to study metal-metal interactions in fish at environmentally relevant concentrations.

In a previous paper (Pelgrom et al., 1994a), interactions between $\mathrm{Cu}$ and $\mathrm{Cd}$ on whole body metal accumulation in juvenile tilapia during waterborne metal exposure were demonstrated. The present study examines $\mathrm{Cu}-\mathrm{Cd}$ interactions in mature tilapia, paying particular attention to organs with diverse biological functions, because it is anticipated that differences in metal accumulation between organs will be related to their functions. Organ metal concentration or metalmetal interaction at this level may be a link to toxicity (Foulkes, 1990; Landrum et al., 1992). In keeping with this, it has recently been suggested that metal concentrations in the organs of fish, rather than the metal concentrations in the ambient water, could be used as a biomonitor for water pollution in natural freshwaters (Handy, 1992).

We have investigated the effects of two concentrations of $\mathrm{Cu}$ and $\mathrm{Cd}$, single as well as in combination, over 6 days on the $\mathrm{Cu}$ and $\mathrm{Cd}$ concentration of organs associated with osmoregulation (gills), metal detoxification (liver, kidney), digestion (intestine), neuro-endocrine regulation (brain, head kidney), locomotion (muscle) 
and reproduction (gonads). At one intermediate concentration of $\mathrm{Cu}$ and $\mathrm{Cd}$, gills and liver were compared after 6 and 11 days of exposure, to compare effects of a more prolonged exposure on metal accumulation and interaction.

\section{MATERIALS AND METHODS}

\section{Fish and control water conditions}

Tilapia (Oreochromis mossambicus) were obtained from our own laboratory stock. Fish were kept, from 9 days after hatching, in artificial freshwater with undetectable $\mathrm{Cu}$ and $\mathrm{Cd}$ concentrations (detection levels below 0.1 and $0.01 \mu \mathrm{g} \mathrm{litre}^{-1}$, respectively). The artificial freshwater consisted of demineralized water supplemented with $1.3 \mathrm{mM} \mathrm{NaHCO}, 0.5 \mathrm{mM} \mathrm{CaCl}_{2}, 0.06 \mathrm{mM} \mathrm{KCl}$ and $0.2 \mathrm{mM} \mathrm{MgCl}_{2}$, at $\mathrm{pH}$ 7.8. The composition and preparation of the water was based on the EEC instructions for artificial water for use in toxicity studies in fish (EEC Directives 84/449/EEC Annex 5 method c1: Acute toxicity for fish). Water was continuously aerated, filtered and subjected to flow-through, resulting in water of constant quality and with a stable $\mathrm{pH}(\mathrm{pH}=7.6)$. The light/dark regime was $12 / 12 \mathrm{~h}$ and the water temperature $26^{\circ} \mathrm{C}$. Fish were fed commercial tropical fishfood Tetramin $^{\mathrm{TM}}, 2 \% \mathrm{dw} / \mathrm{ww}$ per day. The food was eaten within $1 \mathrm{~min}$. The $\mathrm{Cu}$ and $\mathrm{Cd}$ contents of the food were: $9.86 \pm 0.16 \mu \mathrm{g} \mathrm{Cu} \mathrm{g}^{-1}$ dry food and $0.22 \pm 0.01 \mu \mathrm{g} \mathrm{Cd}$ $\mathrm{g}^{-1}$ dry food (means $\pm \mathrm{SE} ; n=10$ ).

\section{Experimental design}

Six weeks before the start of the experiments, sexually mature female fish (mean weight $20 \mathrm{~g}$ ) were divided into four groups of 14 fish each, and kept in 80-litre aquaria with continuously filtered and refreshed artificial freshwater by means of flow-through. The experiment started with the connection (by means of a 16 channel peristaltic pump; Watson Marlow) of each of the aquaria to its own reservoir filled with artificial freshwater with or without (controls) a well-defined metal concentration (added as nitrate; Spectrosol, BDH, England). During the first $6 \mathrm{~h}$ the flow rate was $4.51 \mathrm{~h}^{-1}$, followed by a flow rate of 1.5 $1 \mathrm{~h}^{-1}$. In this way, the metal concentrations in the aquaria were gradually raised, reaching a plateau after $18 \mathrm{~h}$. The measured concentrations deviated maximally $5 \%$ from the nominal concentrations (Pelgrom et al., 1994a). Two experiments were performed, with LOW and $\mathrm{HIGH} \mathrm{Cu}$ and $\mathrm{Cd}$ concentrations. The experiment with the HIGH metal concentrations was performed first, followed by experiments with LOW concentrations. The experimental period lasted 6 days. In an additional experiment with intermediate metal concentrations (50 $\mu \mathrm{g} \mathrm{Cu}$ litre $^{-1}$ and $20 \mu \mathrm{g} \mathrm{Cd} \mathrm{litre}^{-1}$ ), fish were exposed over 6 and 11 days (Table 1).

Feeding was ended the day prior to sacrifice. $\mathrm{Cu}$ and $\mathrm{Cd}$ concentrations in both stock solutions and aquaria were monitored every hour during the first $6 \mathrm{~h}$, and at least once a day during the rest of the exposure period. Water samples were acidified with nitric acid in a final
Table 1. Cu and $\mathrm{Cd}$ concentrations in the aquaria of the metal exposed fish

\begin{tabular}{lrcc} 
& {$[\mathrm{Cu}]$} & {$[\mathrm{Cd}]$} & {$[\mathrm{Cu}]+[\mathrm{Cd}]\left(\mu \mathrm{g} \mathrm{litre}^{-1}\right)$} \\
\hline 6 Days & & & \\
LOW & 20 & 5 & $20+5$ \\
HIGH & 100 & 35 & $100+35$ \\
6 and 11 days & 50 & 20 & $50+20$ \\
\hline
\end{tabular}

concentration of $0.2 \%(\mathrm{v} / \mathrm{v})$. Water $\mathrm{Cu}$ and $\mathrm{Cd}$ concentrations were determined with a flameless Atomic Absorption Spectrometer (AAS, Philips PU9200) connected with an electrothermal atomiser (Philips PU9390X). After exposure, the fish were killed by spinal dissection. Gills, head kidney, brain, liver, intestine (after removal of contents), kidneys, gonads (LOW experiment only) and white muscle were dissected carefully. The tissues were weighed, lyophilized and, after determination of the dry weights, digested with nitric acid (65\% $\mathrm{HNO}_{3}$, ultrapur, Merck). Finally, the samples were dissolved in $0.2 \% \mathrm{HNO}_{3}$, and stored at $4^{\circ} \mathrm{C}$ until metal analysis by means of AAS. $\mathrm{Cu}$ and $\mathrm{Cd}$ determinations in the tissues were performed under standard matrix conditions, with the exception of $\mathrm{Cd}$ determination in the gonads and muscle. The $\mathrm{Cd}$ concentrations in the latter tissues were determined in the presence of a matrix modifier (AAS matrix modifier, Merck). Interference between $\mathrm{Cu}$ and $\mathrm{Cd}$ during measurements can be excluded, as has been demonstrated previously (Pelgrom et al., 1994a). From the (wet) weights of the the gonads and the total body weight, the Gonad Somatic Index (GSI) was determined, with the gonad weight expressed as a percentage of the total body weight.

\section{Statistics}

Data are presented as means \pm SE. For statistical evaluation the Student's $t$-test was applied, and significant differences between control and metal exposed groups are indicated by asterisks, whereas significant differences between single metal and $\mathrm{Cu}-\mathrm{Cd}$ co-exposed groups are indicated by circles: ${ }^{*}$ or ${ }^{\circ}: P<0.05 ;{ }^{* *}$ or ००: $P<0.02$; $^{* * *}$ or $000: P<0.01$; and ${ }^{* * * *}$ or ${ }^{\circ 000:} P$ $<0.001$.

\section{RESULTS}

During all experiments, no mortality occurred, and no differences in the feeding behaviour and body weights between the experimental and control groups were observed. The water in the aquaria was continuously refreshed by means of flow-through, resulting in water of constant quality, as demonstrated by the constant $\mathrm{pH}$, and no changes in ammonia concentrations (data not shown). The results of the 6-day metal exposures on organ metal concentrations are presented in Fig. 1, Fig. 2, Fig. 3 and Fig. 4(A), with LOW: $5 \mu \mathrm{g} \mathrm{Cd} \mathrm{litre}{ }^{-1}$ and/or 

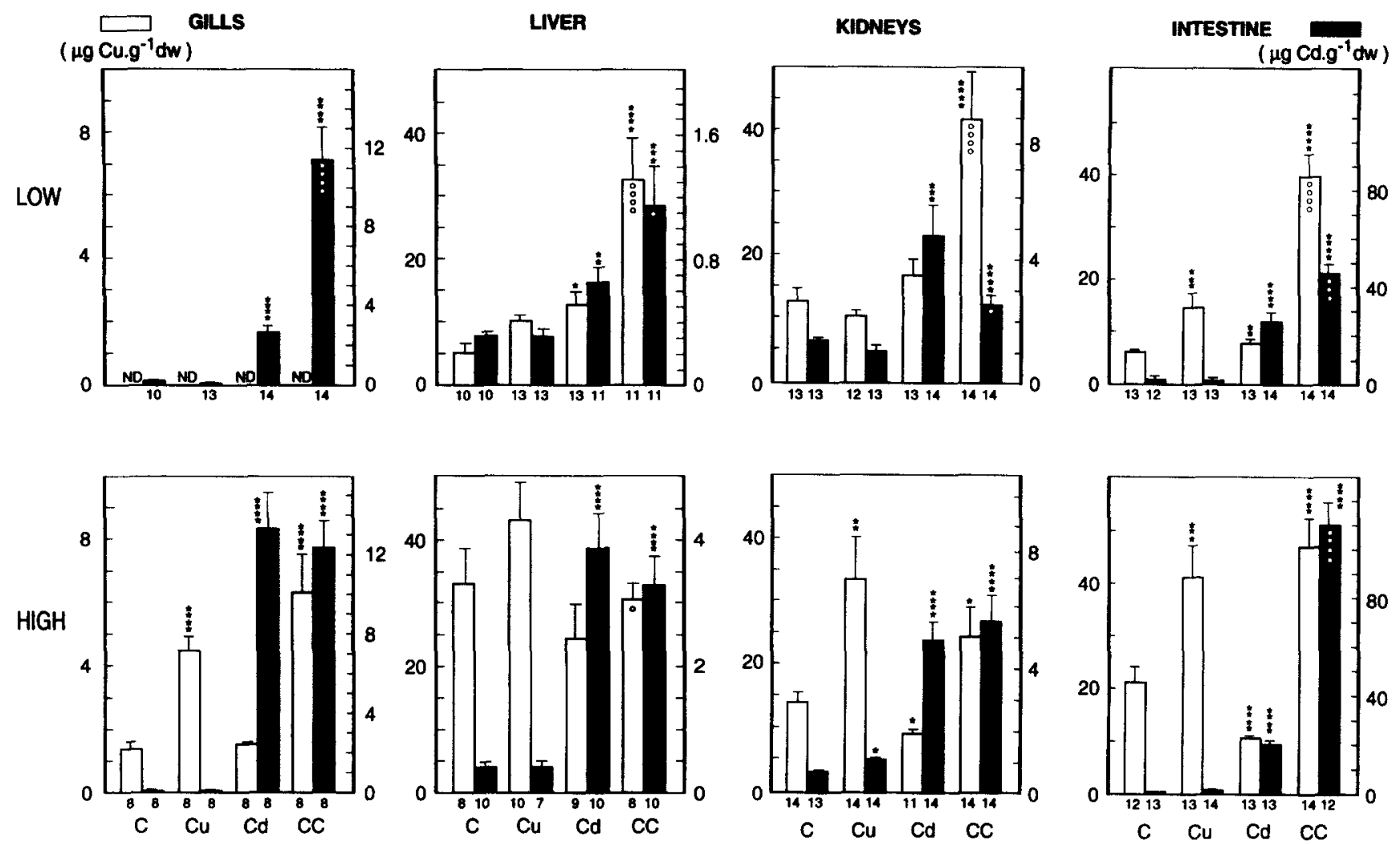

Fig. 1. Concentrations of $\mathrm{Cu}$ (open bars) and $\mathrm{Cd}$ (closed bars) in the gills, liver, kidneys and intestine of fish exposed over 6 days to LOW (5 $\mu \mathrm{g} \mathrm{Cd} \mathrm{litre}^{-1}$ and/or $20 \mu \mathrm{g} \mathrm{Cu}$ litre ${ }^{-1}$; upper panels) or HIGH (35 $\mu \mathrm{g} \mathrm{Cd} \mathrm{litre}^{-1}$ and/or $100 \mu \mathrm{g} \mathrm{Cu}$ litre ${ }^{-1}$; lower panels) metal concentrations. The $\mathrm{Cu}$ concentration is expressed on the left axis and the $\mathrm{Cd}$ concentration on the right axis. The $\mathrm{Cu}$ and $\mathrm{Cd}$ concentrations in the organs are given of the controls $(\mathrm{C}), \mathrm{Cu}$ exposed $(\mathrm{Cu}), \mathrm{Cd}$ exposed $(\mathrm{Cd})$ and $\mathrm{Cu}+\mathrm{Cd}$ co-exposed $(\mathrm{CC})$ fish successively. Asterisks indicate significant differences between control and experimental fish, circles indicate significant differences between single metal exposed fish and $\mathrm{Cu}+\mathrm{Cd}$ co-exposed fish. The number of fish per group is indicated under the bar. In the LOW group, $\mathrm{Cu}$ was not determined (ND) in the gills.
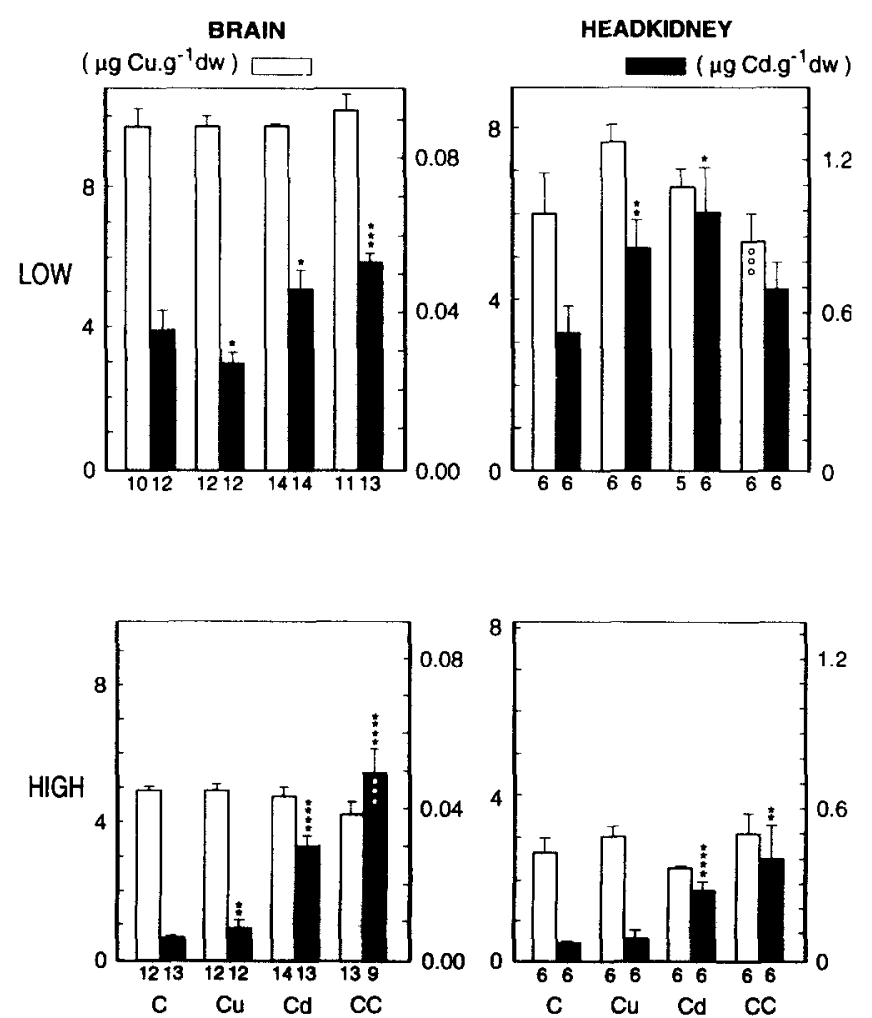

Fig. 2. Concentrations of $\mathrm{Cu}$ (open bars) and $\mathrm{Cd}$ (closed bars) in brain and head kidney of fish exposed during 6 days to LOW or HIGH $\mathrm{Cu}$ and $\mathrm{Cd}$ concentrations. Symbols are used in the the same way as described in Fig. 1.
$20 \mu \mathrm{g} \mathrm{Cu}$ litre ${ }^{-1}$, and HIGH: $35 \mu \mathrm{g} \mathrm{Cd} \mathrm{litre}{ }^{-1}$ and/or $100 \mu \mathrm{g} \mathrm{Cu}$ litre $^{-1}$. Throughout the organs and concentrations, only incidental differences in the per cent water content were observed (data not shown). Therefore, $\mathrm{Cu}$ and $\mathrm{Cd}$ concentrations in the organs are expressed as dry weights.

\section{Tissue Cu concentration}

\section{LOW}

Effects of $\mathrm{Cu}$. Cu-exposure resulted in increased $\mathrm{Cu}$ concentrations in the intestine, muscle and gonads.

Effects of $\mathrm{Cd}$. Compared to control fish, an increased $\mathrm{Cu}$ concentration in the liver and intestine was observed in fish exposed to Cd singly.

Compared to fish exposed to $\mathrm{Cu}$ singly, significantly more $\mathrm{Cu}$ accumulation was observed in the liver, kidneys and intestine of $\mathrm{Cu}-\mathrm{Cd}$ co-exposed fish. In contrast, the $\mathrm{Cu}$ concentrations in the head kidney and muscle of $\mathrm{Cu}-\mathrm{Cd}$ co-exposed fish were lower than those observed in $\mathrm{Cu}$ exposed fish. As a result, the $\mathrm{Cu}$ concentration in the head kidney of fish co-exposed to $\mathrm{Cu}$ and $\mathrm{Cd}$ was not statistically different from the controls.

\section{$H I G H$}

Effects of $\mathrm{Cu}$. Exposure to $100 \mu \mathrm{g} \mathrm{Cu}$ litre $^{-1}$ resulted in accumulation of $\mathrm{Cu}$ in the gills, kidneys, intestine and muscle. 
Effects of $\mathrm{Cd}$. The $\mathrm{Cu}$ concentration in the kidneys and intestine were significantly lower in $\mathrm{Cd}$-exposed fish than in control fish.

Combined $\mathrm{Cu}-\mathrm{Cd}$ exposure resulted in a lower $\mathrm{Cu}$ concentration in the liver when compared to the liver $\mathrm{Cu}$ concentration of fish exposed to $\mathrm{Cu}$ singly.

\section{Tissue Cd concentration}

\section{LOW}

Effects of Cd. Exposure to $5 \mu \mathrm{g} \mathrm{Cd}$ litre $^{-1}$ resulted in increased $\mathrm{Cd}$ concentrations in all tissues examined.

Effects of $\mathrm{Cu}$. In $\mathrm{Cu}$-exposed fish, the Cd concentration in the brain and gonads were significantly lower, whereas in the head kidney we observed an increase in the $\mathrm{Cd}$ concentration compared to control fish. Combined $\mathrm{Cu}-\mathrm{Cd}$ exposure resulted in an increased $\mathrm{Cd}$ accumulation in the gills, liver, intestine and gonads when compared to fish exposed to $\mathrm{Cd}$ singly. The $\mathrm{Cd}$ concentration in the kidneys of $\mathrm{Cu}-\mathrm{Cd}$ co-exposed fish was lower than in Cd-exposed fish.

\section{$H I G H$}

Effects of $C d$. The Cd concentration was increased in all tissues examined of Cd-exposed fish.

Effects of $\mathrm{Cu}$. In Cu-only exposed fish, the Cd concentration was higher in the kidneys and brain compared to controls. Combined $\mathrm{Cu}-\mathrm{Cd}$ exposure resulted in an increased accumulation of $\mathrm{Cd}$ in the intestine, brain and muscle when compared to fish exposed to Cd singly.

Table 2 shows the $\mathrm{Cu}$ and $\mathrm{Cd}$ concentrations in the gills and liver of fish exposed to $20 \mu \mathrm{g} \mathrm{Cd}$ litre ${ }^{-1}$ and/or $50 \mu \mathrm{g} \mathrm{Cu}$ litre $^{-1}$ after 6 or 11 days of exposure. No differences were observed between the $\mathrm{Cu}$ concentrations of both gills and liver of fish exposed to $\mathrm{Cu}$ over 6 or 11 days. In the liver, 11 days of $\mathrm{Cd}$ exposure resulted in a significantly decreased $\mathrm{Cu}$ concentration. Compared to
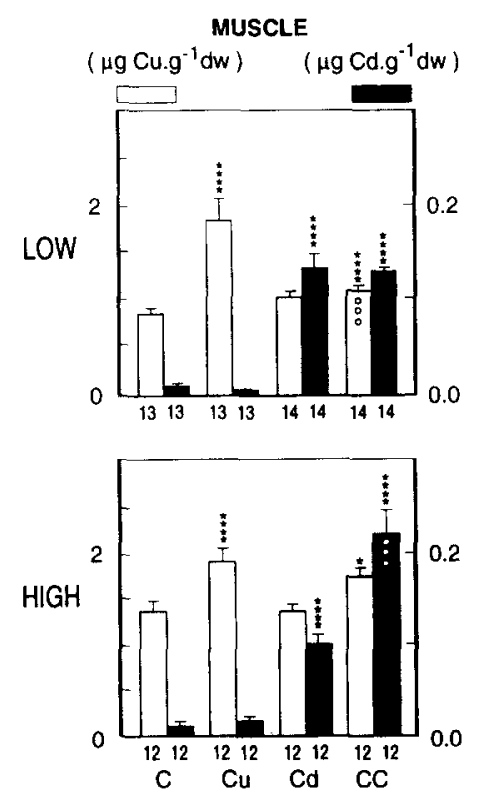

Fig. 3. Concentrations of $\mathrm{Cu}$ (open bars) and $\mathrm{Cd}$ (closed bars) in muscle of fish exposed over 6 days to LOW or HIGH Cu and $\mathrm{Cd}$ concentrations. Symbols are used in the same way as described in Fig. 1. the $\mathrm{Cu}$ concentration in the liver of fish exposed to $\mathrm{Cd}$ over 6 days, the $\mathrm{Cu}$ concentration was lower in the liver of fish exposed to $\mathrm{Cd}$ over 11 days $(P<0.05)$. The $\mathrm{Cd}$ concentration in the gills of $\mathrm{Cd}$ exposed fish doubled between days 6 and 11 of exposure $(P<0.05)$. In the liver of $\mathrm{Cu}$ exposed fish, a significantly decreased $\mathrm{Cd}$ concentration was observed after both 6 and 11 days of exposure. Prolonged $\mathrm{Cu}-\mathrm{Cd}$ exposure resulted in a significant increase in both $\mathrm{Cu}$ and $\mathrm{Cd}$ concentrations in the gills compared to single $\mathrm{Cu}$ or $\mathrm{Cd}$ exposure. In $\mathrm{Cu}-\mathrm{Cd}$ co-exposed fish, significant differences between 6 and 11 days of exposure were observed in the $\mathrm{Cu}$ and Cd concentrations of the gills $(P<0.001$ and $P<0.05$, respectively) and the Cd concentration in the liver $(P<$ $0.05)$.

The relation between GSI and the Cd concentration in the gonads of control, $\mathrm{Cd}$ and $\mathrm{Cu}-\mathrm{Cd}$ co-exposed fish is best described by non-linear functions (Fig. 4(B)). For the $\mathrm{Cu}$-exposed fish, however, no significant relation exists between GSI and the Cd concentration in the gonads. The observed higher $\mathrm{Cd}$ concentrations in the gonads of $\mathrm{Cd}$-and $\mathrm{Cu}-\mathrm{Cd}$-exposed fish compared to the non-Cd-exposed fish (Fig. 4(A)) appeared consistent throughout the GSI range (Fig. 4(B); compare left and right panels).
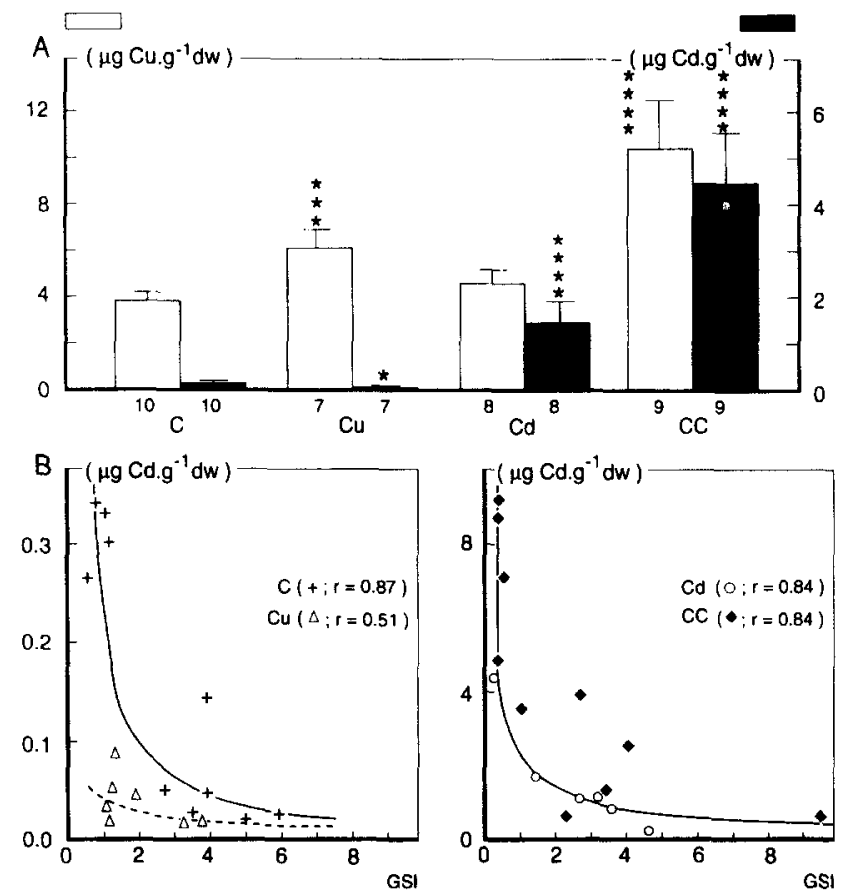

Fig. 4. (A ) $\mathrm{Cu}$ (open bars) and $\mathrm{Cd}$ (closed bars) concentrations in gonads of fish exposed for 6 days to $5 \mu \mathrm{g} \mathrm{Cd} \mathrm{litre}{ }^{-1}$ (Cd), $20 \mu \mathrm{g} \mathrm{Cu}$ litre $^{-1}(\mathrm{Cu})$ or co-exposed to $5 \mu \mathrm{g} \mathrm{Cd} \mathrm{litre}{ }^{-1}+$ $20 \mu \mathrm{g} \mathrm{Cu} \mathrm{litre}^{-1}(\mathrm{CC})$. Symbols are used in the same way as described in Fig. 1. (B) Relationship between the Cd concentration in the gonads and the GSI of the exposed fish described in (A). In control and $\mathrm{Cu}$ exposed fish, the relation between the GSI and the Cd concentration is best described by $y=0.23 x^{-1.17}\left({ }^{* * * *}\right)$ and $y=0.04 x^{-0.51}$ (ns), respectively. In the $\mathrm{Cd}$ and $\mathrm{Cu}-\mathrm{Cd}$ co-exposed fish, the GSI and the $\mathrm{Cd}$ concentration in the gonads are related in a comparable way, and can be best described by the function $y=2.21 x^{-0.73}\left({ }^{* * * *}\right)$, with $y$ representing the $\mathrm{Cd}$ concentration in the gonads and $x$ representing the GSI. 
Table 2. Concentrations of $\mathrm{Cu}$ and $\mathrm{Cd}$ in the gills and the liver of fish exposed for 6 or 11 days to $20 \mu \mathrm{g} \mathrm{Cd} \mathrm{litre}{ }^{-1}$ (Cd), $50 \mu \mathrm{g} \mathrm{Cu}$ litre $^{-1}(\mathrm{Cu})$ or co-exposed to $20 \mu \mathrm{g} \mathrm{Cd} \mathrm{litre} \mathrm{g}^{-1}+50 \mu \mathrm{g} \mathrm{Cu}$ litre ${ }^{-1}(\mathrm{CC})$. Asterisks indicate significant differences between control and metal-exposed fish, while circles indicate significant differences between single metal exposed fish and $\mathrm{Cu}+\mathrm{Cd}$ co-exposed fish

\begin{tabular}{|c|c|c|c|c|c|}
\hline & & Control & $\mathrm{Cu}$ & $\mathrm{Cd}$ & $\mathrm{CC}$ \\
\hline \multicolumn{6}{|c|}{$[\mathrm{Cu}]\left(\mu \mathrm{g} \cdot \mathrm{g}^{-1}\right.$ dry wt $)$} \\
\hline \multirow[t]{2}{*}{ Gills } & 6 days & $(n=5) 1.65 \pm 0.17$ & $3.19 \pm 0.18^{* * *}$ & $1.64 \pm 0.19$ & $2.79 \pm 0.17^{* * *}$ \\
\hline & 11 days & $(n=9) 1.59 \pm 0.19$ & $3.22 \pm 0.23^{* * * *}$ & $1.81 \pm 0.18$ & $5.69 \pm 0.60^{* * *} \bullet \bullet$ \\
\hline \multirow[t]{2}{*}{ Liver } & 6 days & $(n=10) 73.1 \pm 12.3$ & $100.6 \pm 1.26$ & $66.6 \pm 9.2$ & $134.1 \pm 18.6^{* *}$ \\
\hline & \multicolumn{5}{|c|}{$[\mathrm{Cd}]\left(\mu \mathrm{g} \cdot \mathrm{g}^{-1} \mathrm{dw}\right)$} \\
\hline \multirow[t]{2}{*}{ Gills } & 6 days & $(n=5) 0.06 \pm 0.01$ & $0.07 \pm 0.01$ & $2.67 \pm 0.54^{* * * *}$ & $7.41 \pm 1.52^{* * * * \bullet \bullet \bullet}$ \\
\hline & 11 days & $(n=9) 0.12 \pm 0.04$ & $0.11 \pm 0.02$ & $6.13 \pm 1.24^{* * * *}$ & $20.98 \pm 4.99^{* * * \bullet \bullet}$ \\
\hline \multirow[t]{2}{*}{ Liver } & 6 days & $(n=10) 0.31 \pm 0.04$ & $0.19 \pm 0.04^{*}$ & $8.96+1.50^{* * * *}$ & $12.89 \pm 2.85^{* * * *}$ \\
\hline & 11 days & $(n=9) 0.39 \pm 0.12$ & $0.20 \pm 0.03^{*}$ & $15.59 \pm 5.23^{* * *}$ & $7.07 \pm 0.93^{* * * *}$ \\
\hline
\end{tabular}

\section{DISCUSSION}

The results demonstrate organ specific $\mathrm{Cu}-\mathrm{Cd}$ interactions after single and co-exposure of tilapia via the water. Four major conclusions can be drawn from the present study. Firstly, compared to single metal exposed fish, $\mathrm{Cu}-\mathrm{Cd}$ co-exposure resulted in significantly different $\mathrm{Cu}$ and/or $\mathrm{Cd}$ concentrations in the gills, liver, kidneys, intestine and gonads. Secondly, these metal interactions were most pronounced in the LOW group. Thirdly, in the gills of $\mathrm{Cu}-\mathrm{Cd}$ co-exposed fish, accumulation and impact of the interactions were time dependent. Finally, $\mathrm{Cu}$ and $\mathrm{Cd}$ accumulated in notable amounts in the intestinal wall.

$\mathrm{Cu}-\mathrm{Cd}$ accumulation and interactions were studied after 6 and 11 days of exposure, and therefore conclusions on $\mathrm{Cu}-\mathrm{Cd}$ accumulation and interactions are restricted to the exposure regimes studied. However, it has been demonstrated that accumulation and toxicity of the metals are mainly critical during an exposure period of days rather than weeks (Gill et al., 1992; Carbonell and Tarazona, 1994).

\section{Water content}

Exposure of the fish to $\mathrm{Cu}$ and $\mathrm{Cd}$, both singly and combined, did not affect the water content of any of the organs studied, which contrasts with previous results on juvenile tilapia exposed to identical metal regimes (Pelgrom et al., 1994a). This may relate to an increased sensitivity of younger life-stages to osmoregulatory disturbances, i.e. water balance, since the weight-specific surface area of the gills in juvenile fish is nearly two times higher than that of mature fish (Morgan, 1971).

\section{Gills}

$\mathrm{Cu}$ or $\mathrm{Cd}$ exposure resulted in a significant increase of either metal concentration in the gills. This accumulation was concentration-and time-dependent, only for Cd. Increased metal concentrations were also observed in $\mathrm{Cu}$-exposed carp, brown bullhead and roach (Yamamoto et al., 1977; Stagg and Shuttleworth, 1982; Segner, 1987) but not in rainbow trout (Laurén and McDonald, 1987), and in Cd-exposed rainbow trout, pike and American eel (Brown et al., 1986; Norey et al.,
1990; Gill et al., 1992). Metal-metal interactions after single metal exposure were shown by Gill et al. (1992) who reported an increased $\mathrm{Cu}$ concentration in the gills of eels after $\mathrm{Cd}$ exposure. Previous experiments with single metal exposed fish have shown effects of sublethal concentrations of $\mathrm{Cu}$ or $\mathrm{Cd}$ on the number and function of ion transporting cells in the gills (Baker, 1969; Verbost et al., 1987; Reid and McDonald, 1988; Pratap and Wendelaar Bonga, 1993; Pelgrom et al., 1995). Exposure to low $\mathrm{Cd}$ concentrations resulted in an unexpectedly high increase in metal concentration in the gills. However, the free available ionic metal concentration is not necessarily equivalent to the total water metal concentration to which the gill is exposed (Playle et al., 1992), since: (i) the $\mathrm{pH}$ at the gill surface is lower than the water, due to local release of carbon dioxide, and this facilitates the release of metal ions from complexes (Cusimano et al., 1986), and (ii) the amount of mucus on the gill surface increases during metal exposure (Handy and Eddy, 1991), which may contribute to higher metal concentrations at the gill surface (Reid and McDonald, 1991). Both phenomena might be relatively more important at low-water metal concentrations. In this study, co-exposure to $\mathrm{Cu}-\mathrm{Cd}$ resulted in an even greater accumulation of $\mathrm{Cd}$ than when compared to single $\mathrm{Cd}$ exposure. At present it is not clear to what extent these increased metal concentrations affect the function of ion-transporting cells.

\section{Liver and kidneys}

Exposure to $\mathrm{Cu}$ over 6 as well as 11 days had no effect on the $\mathrm{Cu}$ concentration in the liver, whereas the $\mathrm{Cu}$ concentration in the kidney increased significantly after exposure to $100 \mu \mathrm{g} \mathrm{Cu}$ litre $^{-1}$. Opposing effects have been reported in most other fish species. $\mathrm{Cu}$ has been shown to accumulate in both the liver and kidneys of catfish (Brungs et al., 1973) and carp (Yamamoto et al., 1977), whereas Stagg and Shuttleworth (1982) registered a decreased $\mathrm{Cu}$ concentration in the liver of flounder after $\mathrm{Cu}$ exposure in seawater. Starved, but not fed, roach accumulated significant amounts of $\mathrm{Cu}$ in the liver (Segner, 1987). Our experiments were performed with fed tilapia, and this may partly account for the absence of $\mathrm{Cu}$ accumulation in this study. In contrast to 
other species, however, tilapia accumulated extremely high amounts of $\mathrm{Cu}$ in the intestinal wall, which may partly explain the absence of $\mathrm{Cu}$ accumulation in the liver after $\mathrm{Cu}$ exposure. This will be discussed in the following section.

$\mathrm{Cd}$ exposure resulted in an increased $\mathrm{Cd}$ content of both liver and kidneys, and this agrees with the findings of Gill et al. (1992) on eel. The liver and kidneys play a crucial role in detoxification and excretion of toxicants mainly through the induction of metal-binding proteins such as metallothioneins (MTs; Klaverkamp et al., 1984; Cousins, 1985). Relatively few in-vivo studies concerning both metal accumulation and MT-induction investigated the effects of $\mathrm{Cu}-\mathrm{Cd}$ interactions during single and combined exposures. Both in liver and kidneys, the lowest concentrations used in combination, 5 $\mu \mathrm{g}$ litre $^{-1} \mathrm{Cd}$ and $20 \mu \mathrm{g}$ litre $^{-1} \mathrm{Cu}$, resulted in significantly increased $\mathrm{Cu}$ concentrations when compared to single $\mathrm{Cu}$ exposure. This suggests a disturbance of the $\mathrm{Cu}$ metabolism which might involve interactions between $\mathrm{Cu}$ and $\mathrm{Cd}$ during binding to MT. Changes of the $\mathrm{Cu}$ content of the liver and kidney following single Cd exposure are known from studies on mammals (Suzuki et al., 1983; Chmielnicka et al., 1985), and eels (Gill et al., 1992). Our results demonstrate similar interactions in combined $\mathrm{Cu}$-Cd-exposed fish which occur in mixtures at very low, environmentally relevant, metal concentrations.

\section{Intestine}

Exposure to waterborne $\mathrm{Cu}$ or $\mathrm{Cd}$ resulted in a high increase of both metals in the intestinal wall. This is surprising because freshwater fish are known to drink very little (Potts et al., 1967). In $\mathrm{Cu}-\mathrm{Cd}$ co-exposed fish, the $\mathrm{Cd}$ increase was even more pronounced than in $\mathrm{Cd}$ exposed fish. After intravenous Cd administration, significantly increased $\mathrm{Cd}$ concentrations were found in the intestinal wall of rats and mice (Berlin and Ullberg, 1963; Stonard and Webb, 1976; Barański, 1987). Stonard and Webb (1976) reported that the $\mathrm{Cd}$ in the intestinal mucosa could be recovered in the fraction containing MT. Few reports are available on the effects of waterborne metal exposure on the intestinal wall of freshwater fish. Exposure of freshwater fish to high concentrations of $\mathrm{Cu}$ (Yamamoto et al., 1977) or $\mathrm{Cd}$ (Gill et al., 1992) resulted in a significant increase of these metals in the intestine. In our study, compared to single metal exposed fish, combined $\mathrm{Cu}-\mathrm{Cd}$ exposure resulted in even higher $\mathrm{Cu}$ (LOW) and $\mathrm{Cd}$ concentrations. In line with this, Gill et al. (1992) observed indications for interaction between $\mathrm{Cd}$ and $\mathrm{Cu}$ in the intestine of $\mathrm{Cd}$ exposed eels. The $\mathrm{Cu}$ and $\mathrm{Cd}$ content of the food can not account for the amounts of metals found in the intestinal wall of our tilapia, since the contribution of $\mathrm{Cd}$ from the food can maximally account for $2.5 \%$ of total $\mathrm{Cd}$ concentration of the intestine. Also drinking could not explain this phenomenon (Gill et al., 1992), since it would imply an exceptionally high drinking rate (at least $60 \mathrm{ml} \mathrm{h}^{-1}$ in the LOW group, assuming that $100 \%$ of the $\mathrm{Cu}$ in the water is taken up). It is therefore more likely that in tilapia the intestine wall serves as a storage organ and possibly excretion route for heavy metals, as has earlier been suggested for rats (Stonard and Webb, 1976). A negative consequence of this mechanism might be, that the high metal concentrations may affect the transport functions of the intestine. The results of in-vitro experiments with tilapia intestinal basolateral plasma membrane preparations have shown that $\mathrm{Cd}^{2+}$ inhibits the active uptake of calcium (Schoenmakers et al., 1992).

The metal accumulation in the intestinal wall might be a specific mechanism for tilapia, because in general in fish about $95 \%$ of the whole body $\mathrm{Cu}$ accumulation was allocated into the liver (Stagg and Shuttleworth, 1982; Laurén and McDonald, 1987). Perhaps an efficient accumulation and excretion route via the intestine contributes to the metal tolerance of tilapia, which is higher than in other species studied.

\section{Brain and head kidney}

Because $\mathrm{Cd}$, but not $\mathrm{Cu}$, accumulated significantly in both the brain and head kidney after $\mathrm{Cd}$ exposure, the blood-brain barrier might function better for $\mathrm{Cu}$ than for Cd. Generally, brain and head kidneys are not considered to be a storage place for metals during exposure (Pelgrom et al., 1994b). In stone loach and carp, waterborne $\mathrm{Cu}$ exposure respectively increased (Solbé and Cooper, 1976) and decreased (Yamamoto et al., 1977) $\mathrm{Cu}$ concentrations in the brain. Although increased $\mathrm{Cd}$ concentrations in fish brains were observed previously, this effect does not appear to be related to the ambient Cd concentration (Gill et al., 1992). Effects of Cd exposure on the $\mathrm{Cu}$ content of the brain was observed in studies with rats (Chmielnicka et al., 1985) and eel (Gill et al., 1992). Copper ions may interfere with the control of GnRH (gonadotrophin-releasing hormone) release, whereas $\mathrm{Cu}$ deficiency leads to infertility in rats and guinea-pigs (Burrows and Barnea, 1982; Barnea et al., 1986).

To our knowledge, there are no other studies concerning $\mathrm{Cu}, \mathrm{Cd}$ or $\mathrm{Cu}-\mathrm{Cd}$ co-exposure on the metal content of the head kidney of fish. In mammals, the adrenal is the endocrine organ most sensitive to chemical induced lesions (Ribelin, 1984). In fish, the cortisol producing interrenal tissue, located in the head kidney, plays a key role in the regulation of ion-homeostasis and in the stress response, via the release of cortisol (Donaldson, 1981). The amount of metal accumulated in the head kidney tissue is remarkably lower than in the kidney. This is in keeping with observations in tilapia that renal and interrenal tissue, despite their common origin, are two separate compartments with different functions (Nandi and Bern, 1960).

\section{Muscle}

In contrast to our data, other researchers found no detectable metal concentrations in fish muscle after waterborne $\mathrm{Cu}$ (Yamamoto et al., 1977) or Cd exposure (Hawkins et al., 1980). This probably relates to the difficulty of detecting metals in muscle tissue, because its 
high protein content influences metal measurements. Such problems can be solved by applying a matrixmodifier during metal detection (Dabeka and Ihnat, 1987), as used presently. Other authors reporting detectable $\mathrm{Cu}$ or $\mathrm{Cd}$ concentrations found no differences in metal content between control and metal exposed fish. It is important to note that we have reared fish under metal-free water conditions, which is reflected in low metal levels in the control fish. In none of the experimental groups did metal concentrations in the muscle exceed those in the directives of the Food and Drug Act for edibility of fish. From these directives, the norm of safe levels of toxic metals in freshwaters have been deduced (WVC, 1992). Results from the present study and from the study of Gill et al. (1992) demonstrate that it is difficult to relate tissue $\mathrm{Cu}$ and $\mathrm{Cd}$ concentrations to water metal concentration or exposure time, which in particular applies to $\mathrm{Cu}-\mathrm{Cd}$ co-exposed fish.

\section{Gonads}

It is remarkable that, in this tissue, at the low water concentrations used, significantly higher concentrations of $\mathrm{Cd}$ were found after co-exposure than after single metal exposure. In a concomitant study on male tilapia, $\mathrm{Cu}-\mathrm{Cd}$ co-exposure resulted in an even more pronounced difference in the concentrations in the gonads, a three- and eight-fold additional increase of $\mathrm{Cu}$ and $\mathrm{Cd}$, respectively, compared to single metal exposure (our unpublished observations). Although no significant effects on the average GSI were noticeable after 6 days of exposure, in all groups of fish there was a negative relationship between the Cd concentration and the GSI. It is of interest, that the gonadal Cd concentration of the $\mathrm{Cd}$ and $\mathrm{Cu}-\mathrm{Cd}$ co-exposed fsh was higher than in controls over the entire GSI range, but particularly so at the lower GSI. This indicates that $\mathrm{Cd}$ accumulation is predominantly associated with the connective and endocrine tissues. The observed higher $\mathrm{Cd}$ concentrations at high GSI indicates, that in the mature ovaria, $\mathrm{Cd}$ also accumulated in the eggs. Increased metal concentrations in the gonads likely implicate a direct burden for reproduction and/or for young fish in addition to indirect effects on regulatory systems at other sites. Studies of Eaton (1973) and McFarlane and Franzin (1978) showed that exposure to mixtures of trace metals decreased the reproductive success of fathead minnows and white suckers.

Previously, we demonstrated $\mathrm{Cu}-\mathrm{Cd}$ interactions on whole body metal accumulation during waterborne metal exposure of juvenile tilapia (Pelgrom et al., 1994a). Data in the present study show that interactions observed are organ specific and therefore data for most organs are not representative for the whole organism. Furthermore, $\mathrm{Cu}-\mathrm{Cd}$ interactions already occur at low, environmentally relevant metal concentrations in the water. The data in the present study substantiate the observations of Handy (1992) that metal concentrations in the organs of fish, rather than the metal concentrations in the water, are suitable for environmental monitoring, especially when trying to relate the toxicity of metals to the biological function of specific organs.

\section{ACKNOWLEDGEMENTS}

The authors would like to thank Mr J. Eygensteyn for analytical assistance and $\mathrm{Mr} \mathrm{T}$. Spanings for animal care. This study was supported by the Life Sciences Foundation (SLW), which is subsidized by the Netherlands Organization for Scientific Research (NWO).

\section{REFERENCES}

Baker, J. T. P. (1969). Histological and electron microscopical observations on copper poisoning in the winter flounder (Pseudopleuronectus americanus). J. Fish. Res. Bd Can., 26, 2785-93.

Barański, B. (1987). Effect of cadmium on prenatal development and on tissue cadmium, copper, and zinc concentrations in rats. Environ. Res., 42, 54-62.

Barnea, A., Cho, G. \& Colombani-Vidal, M. (1986). Amplification of prostaglandin $\mathrm{E}_{2}$ stimulation of luteinizing hormone-releasing hormone release from median eminence explants: A metal(II)-specific effect of chelated copper. Brain Res., 384, 101-5.

Berlin, M. \& Ullberg, S. (1963). The fate of $\mathrm{Cd}^{109}$ in the mouse. Arch. Environ. Health, 7, 686-93.

Bremner, I. (1974). Heavy metal toxicities. Quart. Rev. Biophys., 7, 75-124.

Brown, M. W., Thomas, D. G., Shurben, D., Solbe, J. F. Kay, J. \& Cryer, A. (1986). A comparison of the differential accumulation of cadmium in the tissues of three species of freshwater fish, Salmo gairdneri, Rutilus rutilus and Noemacheilus barbatulus. Comp. Biochem. Physiol., 84C, 213-17.

Brungs, A., Leonard, E. N. \& McKim, J. M. (1973). Acute and long-term accumulation of copper by the brown bullhead Ictalurus nebulosus. J. Fish. Res. Bd Can., 30, 583-6.

Buckley, J. T., Roch, M., McCarter, J. A., Rendell, C. A. \& Matheson, A. T. (1982). Chronic exposure of coho salmon to sublethal concentrations of copper -1. Effect on growth, on accumulation and distribution of copper, and on copper tolerance. Comp. Biochem. Physiol., 72C, 15-19.

Burrows, G. H. \& Barnea, A. (1982). Copper stimulates the release of luteinizing hormone releasing hormone from isolated hypothalamic granules. Endocrinol., 110, 1456-8.

Carbonell, G. \& Tarazona, T. V. (1994). Toxicokinetics of copper in rainbow trout (Oncorhynchus mykiss). Aquat. Toxicol., 29, 213-21.

Chmielnicka, J., Bem, E. M., Brzeźnicka, E. A. \& Kasperek, M. (1985). The tissue disposition of zinc and copper following repeated administration of cadmium and selenium to rats. Environ. Res., 37, 419-24.

Chmielnicka, J. \& Cherian, M. G. (1986). Environmental exposure to cadmium and factors affecting trace-element metabolism and metal toxicity. Biol. Trace Element Res. 10, 243-62.

Christensen, G. M., McKim, J. M., Brungs, W. A. \& Hunt, E. P. (1972). Changes in the blood of the brown bullhead (Icralurus nebulosus Lesueur) following short-and longterm exposure to copper (II). Toxicol. Appl. Pharmacol., 23, 417-27.

Christensen, G. M. \& Tucker, J. H. (1976). Effects of selected water toxicants on the in-vitro activity of fish carbonic anhydrase. Chem. Biol. Interactions, 13, 181-92. 
Cousins, R. J. (1985). Absorption, transport, and hepatic metabolism of copper and zinc: Special reference to metallothionein and ceruloplasmin. Physiol. Rev., 65(2), 238-309.

Cusimano, R. F., Brakke, D. F. \& Chapman, G. A. (1986). Effect of $\mathrm{pH}$ on the toxicities of cadmium, copper, and zinc to steelhead trout (Salmo gairdneri). Can. J. Aquat. Sci., 43, 1497-503.

Dabeka, R. W. \& Ihnat, M. (1987). Methods of cadmium detection. In Cadmium in the Aquatic Environment, ed. J. O. Nriagu \& J. B. Sprague. Adv. Environ. Sci. Technol. Series 19, Wiley-Interscience, New York, USA, pp. 231-63.

Donaldson, E. M. (1981). The pituitary-interrenal axis as an indicator of stress in fish. In Stress and Fish, ed. A. D. Pickering. Academic Press, London, UK, pp. 1-47.

Douben, P. E. T. (1989). Uptake and elimination of waterborne cadmium by the fish Noemacheilus barbatulus L. (stone loach). Arch. Environ. Contam. Toxicol., 18, 576-86.

Eaton, J. G. (1973). Chronic toxicity of a copper, cadmium and zinc mixture to the fathead minnows (Pimephales promelas Rafinesque). Water Res., 7, 1723-36.

Foulkes, E. C. (1990). The concept of critical levels of toxic heavy metals in target tissues. Crit. Rev. Toxicol., 20, 327-39.

Gill, T. S., Bianchi, C. P. \& Epple, A. (1992). Trace metal (Cu and $\mathrm{Zn}$ ) adaptation of organ systems of the american eel, Anguilla rostrata, to external concentrations of cadmium. Comp. Biochem. Physiol., 102C, 361-71.

Handy, R. D. (1992). The assesment of episodic metal pollution. I. Uses and limitations of tissue contaminant analysis in rainbow trout (Oncorhynchus mykiss) after short waterborne exposure to cadmium or copper. Arch. Environ. Contam. Toxicol., 22, 74-81.

Handy, R. D. \& Eddy, F. B. (1991). Effects of inorganic cation on $\mathrm{Na}^{+}$adsorption to the gill and body surface of rainbow trout, Oncorhynchus mykiss, in dilute solutions. Can. J. Fish. Aquat. Sci., 48, 1829-37.

Hawkins, W. E., Tate, L. G. \& Sarphie, T. G. (1980). Acute effects of cadmium on the spot Leiostomus xanthurus (teleostei): Tissue distribution and renal ultrastructure. $J$. Toxicol. Environ. Health., 6, 283-95.

Horning, W. B. \& Nieheisel, T. W. (1979). Chronic effect of copper on the bluntnose minnow, Pimephales notatus (Rafinesque). Arch. Environ. Contam. Toxicol., 8, 545-52.

Karlsson-Norrgren, L., Runn, P., Haux, C. \& Forlin, L. (1985). Cadmium-induced changes in gill morphology of zebrafish, Brachydanio rerio (Hamilton-Buchanan), and rainbow trout, Salmo gairdneri Richardson. J. Fish Biol., 27, 81-95.

Klaverkamp, J. F., Macdonald, W. A., Duncan, D. A. \& Wagemann, R. (1984). Metallothionein and acclimation to heavy metals in fish: A review. In Contaminant Effects on Fisheries, ed. V. W. Cairns, P. V. Hodson \& J. O. Nriagu, Adv. Environ. Sci. Technol. Series 16, Wiley, New York, USA, pp. 99-113.

Landrum, P. F., Lee II, H. \& Lydy, M. J. (1992). Annual review. Toxicokinetics in aquatic systems: model comparisons and use in hazard assessment. Environ. Toxicol. Chem., II, 1709-25.

Laurén, D. J. \& McDonald, D. G. (1987). Acclimation to copper by rainbow trout, Salmo gairdneri: Biochemistry. Can. J. Fish. Aquat. Sci., 44, 105-11.

McCracken, I. R. (1987). Biological cycling of cadmium in fresh water. In Cadmium in the Aquatic Environment, ed. J. O. Nriagu \& J. B. Sprague, Adv. Environ. Sci. Technol. Series 19, Wiley-Interscience, New York, USA, pp. 89-116.

McFarlane, G. A. \& Franzin, W. G. (1978). Elevated heavy metals: A stress on a population of white suckers, Catostomus commersoni, in Hamell Lake, Saskatchewan. $J$. Fish. Res. Bd Can., 35, 963-70.
McKim, J. M., Christensen, G. M. \& Hunt, E. P. (1970). Changes in the blood of brook trout (Salvelinus fontinalis) after short-term and long-term exposure to copper. $J$. Fish. Res. Bd Can., 27, 1883-9.

Morgan, M. (1971). Gill Development, Growth and Respiration in the Trout, Salmo gairdneri. PhD Thesis, University of Bristol, Bristol, UK.

Nandi, J. \& Bern, H. A. (1960). Corticosteroid production by the interrenal tissue of teleost fish. Endocrionol., 66, 295-303.

Norey, C. G., Cryer, A. \& Kay, J. (1990). Cadmium uptake and sequestration in the pike (Essox lucius). Comp. Biochem. Physiol., 95C, 217-21.

Pelgrom, S. M. G. J., Lamers, L. P. M., Garritsen, J. A. M., Pels, B. M., Lock, R. A. C., Balm P. H. M. \& Wendelaar Bonga, S. E. (1994a). Interaction between copper and cadmium during single and combined exposure in juvenile tilapia Oreochromis mossambicus-Influence of feeding condition on whole body metal accumulation and the effect of the metals on tissue water and ion content. Aquat. Toxicol., 30, 117-35.

Pelgrom, S. M. G. J., Lamers, L. P. M., Haaijman, A., Balm, P. H. M., Lock, R. A. C. \& Wendelaar Bonga, S. E. (1994b). Interactions between copper and cadmium during single or combined metal exposure in the teleost fish Oreochromis mossambicus. Heavy metal accumulation and endocrine events. In Sublethal and Chronic Effects of Pollutants on Freshwater Fish, ed. R. Muller \& R. Lloyd. FAO, The University Press, Cambridge, UK, pp. 62-74.

Pelgrom, S. M. G. J., Lock, R. A. C., Balm, P. H. M. \& Wendelaar Bonga, S. E. (1995). Integrated physiological responses of tilapia, Oreochromis mossambicus, to sublethal copper exposure. Aquat. Toxicol., 32, 303-20.

Playle, R. C., Gensemer, R. W. \& Dixon, D. G. (1992). Copper accumulation on gills of fathead minnows: Influence of water hardness, complexation and $\mathrm{pH}$ of the gill microenvironment. Environ. Toxicol. Chem., 11, 381-91.

Potts, W. T. W., Forster, M. A., Rudy, P. P. \& Howells, G. P. (1967). Sodium and water balance in the cichlid teleost Tilapia mossambica. J. Exp. Biol., 47, 461-70.

Pratap, H. B. \& Wendelaar Bonga, S. E. (1993). Effect of ambient and dietary cadmium on pavement cells, chloride cells, and $\mathrm{Na}^{+} / \mathrm{K}^{+}$-ATPase activity in the gills of the freshwater teleost Oreochromis mossambicus at normal and high calcium levels in the ambient water. Aquat. Toxicol., 26, 133-50.

Reid, S. D. \& McDonald, D. G. (1988). Effects of cadmium, copper, and low $\mathrm{pH}$ on ionfluxes in the rainbow trout, Salmo gairdneri. Can. J. Fish. Aquat. Sci., 45, 244-53.

Reid, S. D. \& McDonald, D. G. (1991). Metal binding activity of the gills of rainbow trout (Oncorhynchus mykiss). Can. J. Fish. Aquat. Sci., 48, 1061-8.

Ribelin, W. E. (1984). Effects of drugs and chemicals upon the structure of the adrenal gland. Fundamental Appl. Toxicol., 4, 105-19.

Schoenmakers, Th. J. M., Klaren, P. H. M., Flik, G., Lock, R. A. C., Pang, P. K. T. \& Wendelaar Bonga, S. E. (1992). Actions of cadmium on basolateral plasma proteins involved in calcium uptake by fish intestine. J. Membrane Biol., 127, 161-72.

Segner, H. (1987). Response of fed and starved roach, Rutilus rutilus, to sublethal copper contamination. J. Fish Biol., 30, 423-37.

Solbé, J. F. \& Cooper, V. A. (1976). Studies on the toxicity of copper sulfate to stone loach, Noemacheilus barbatulus in hard water. Water Res., 10, 523-7.

Spehar, R. L. (1976). Cadmium and zinc toxicity to flagfish, Jordanella floridae. J. Fish. Res. Bd Can., 33, 1939-45.

Stagg, R. M. \& Shuttleworth, T. J. (1982). The effects of copper on ionic regulation by the gills of the seawater-adapted flounder (Platichthys fesus L.). J. Comp. Physiol., 149B, 83-90. 
Stonard, M. D. \& Webb, M. (1976). Influence of dietary cadmium on the distribution of the essential metals copper, zinc and iron in tissues of the rat. Chem. Biol. Inter., 15, 349-63.

Suzuki, K. T., Yaguchi, K., Ohnuki, R., Nishikawa, M. \& Yamada, Y. K. (1983). Extent of cadmium accumulation and its effects on essential metals in liver, kidney and body fluids. J. Toxicol. Environ. Health, 11, 713-26.

Verbost, P. M., Flik, G., Lock, R. A. C. \& Wendelaar Bonga, S. E. (1987). Cadmium inhibition of $\mathrm{Ca}^{2+}$ uptake in rainbow trout gills. Am. J. Physiol., 253, R216-R221.

WVC (Ministerie van Welzijn, Volksgezondheid en Cultuur) (1992). Regeling normen zware metalen (Warenwet). Staatscourant 2, Maart 1992, p. 11 (Dutch Department of Welfare, Health and Culture, Official Gazette, March 1992, p. 11).

Yamamoto, Y., Ishii, T. \& Ikeda, S. (1977). Studies on copper metabolism in fishes-II. The site of copper accumulation in the tissues of carp. Bull. Japan Soc. Sci. Fish., 43, $1327-32$. 